\title{
Seroprevalence of Toxoplasma gondii in dogs of riverside communities of Mato Grosso Pantanal, Brazil
}

\author{
Soroprevalência de Toxoplasma gondii em cães de comunidades ribeirinhas \\ do Pantanal de Mato Grosso, Brasil \\ Juliana Yuki Rodrigues ${ }^{1}$; Arleana do Bom Parto Ferreira de Almeida ${ }^{1}$; Eveline da Cruz Boa Sorte ${ }^{1}$; \\ Naiani Domingos Gasparetto ${ }^{1}$; Felipe Augusto Constantino Seabra da Cruz ${ }^{1}$; Valéria Régia Franco Sousa ${ }^{1 *}$ \\ ${ }^{1}$ Faculdade de Medicina Veterinária, Universidade Federal de Mato Grosso - UFMT, Cuiabá, MT, Brasil \\ Received May 30, 2016 \\ Accepted August 23, 2016
}

\begin{abstract}
Toxoplasma gondii is an intracellular protozoan with worldwide distribution and dogs act as sentinels of human infection. This search aimed to determine the occurrence of antibodies against T. gondii in dogs of the communities on the Cuiabá River, Mato Grosso and variables associated with infection. The dogs of the riverside communities in Cuiabá River, which includes Barranco Alto, Praia do Poço, Engenho Velho, Varginha, Bom Sucesso, Passagem da Conceiçáa and São Gonçalo Beira Rio, were evaluated for the presence of $T$. gondii antibodies by indirect immunofluorescence antibody test (IFAT). The prevalence and factors associated with infection were calculated by chi-squared test $\left(\chi^{2}\right)$ or Fisher's exact test, and univariate and multiple analysis. Of the 248 dogs surveyed, 107 (43.1\%) were seropositive for T. gondii. The seroprevalence ranged from $25.6 \%$ to $64.3 \%$. There was no statistically significant difference between the communities studied $(\mathrm{p}>0.05)$. As for the associated factors, the only statistically significant factor was that of dogs living with cats $(\mathrm{p}=0.02)$, with approximately twice the risk of acquiring infection. In conclusion, the seroprevalence in dogs of riverside communities in the Baixada Cuiabana demonstrated that high rates of infection, being the factor associated with infection, contact with domestic cats.
\end{abstract}

Keywords: Toxoplasma gondii, dogs, associated factors, Cuiabá River, Pantanal, Brazil.

\section{Resumo}

Toxoplasma gondii é um protozoário intracelular com distribuição mundial e o cão atua como sentinela para infecção humana. Esta pesquisa teve por objetivo determinar a ocorrência de anticorpos contra T. gondii em cáes de comunidades ribeirinhas ao Rio Cuiabá, Mato Grosso e as variáveis associadas à infecção. Os cáes das comunidades ribeirinhas do Rio Cuiabá, que inclui Barranco Alto, Praia do Poço, Engenho Velho, Varginha, Bom Sucesso, Passagem da Conceição e São Gonçalo Beira Rio, foram avaliados para a presença de anticorpos para T. gondii pela reação de imunofluorescência indireta (IFI). A prevalência e fatores associados com a infecção foram calculados pelo teste de qui-quadrado $\left(\chi^{2}\right)$ ou exato de Fisher, e análise univariada e multivariada. Dos 248 cães estudados, 107 (43,1\%) foram soropositivos para T. gondii. A prevalência variou de $25,6 \%$ a $64,3 \%$. Não houve diferença estatisticamente significativa entre as comunidades estudadas $(\mathrm{p}>0,05)$. Quanto aos fatores associados, o único fator estatisticamente significante o convívio com gatos $(\mathrm{p}=0,02)$, com cerca de duas vezes mais risco de adquirir a infecçáo. Em conclusáo, a soroprevalência em cães de comunidades ribeirinhas da Baixada Cuiabana demonstram altas taxas de infecção, sendo o fator associado à infecção, o contato com gatos domésticos.

Palavras-chave: Toxoplasma gondii, cães, fatores associados, Rio Cuiabá, Pantanal, Brasil.

Toxoplasma gondii is an intracellular protozoan with worldwide distribution that can infect several species of warm-blooded animals (LANGONI et al., 2013). The seroprevalence of T. gondii in Brazil is often high (SOUZA et al., 2003), ranging from 3.1\% to $91 \%$ of the canine population in studies in several states, such as Minas

*Corresponding author: Valéria Régia Franco Sousa. Faculdade de Medicina Veterinária, Universidade Federal de Mato Grosso - UFMT, Avenida Fernando Correa da Costa, 2367, Boa Esperança, CEP 78060-900, Cuiabá, MT, Brasil. e-mail: valeriaregia27@gmail.com
Gerais, Santa Catarina, São Paulo, Rio de Janeiro, Bahia and Para (DUBEY et al., 2012; DREER et al., 2013).

Although cats are the only known hosts that can excrete oocysts into the environment, dogs are considered sentinels for infection of $T$. gondii in humans because they live in close contact with humans and livestock (SOUZA et al., 2003; MILLÁN et al., 2013).

The high prevalence worldwide is related to environmental and socioeconomic factors because the transmission is associated with raw or undercooked meat intake containing protozoan cysts or 
contact with oocysts in the environment and vertical transmission (DUBEY, 2007; FERREIRA et al., 2014). It is estimated that one-third of the human population is infected by the parasite. The majority of infections are asymptomatic; however, T. gondii infection in pregnant women and immunocompromised patients can cause serious illnesses and even death (ZHANG et al., 2015). Similarly, infection in dogs may be asymptomatic, but clinical signs are variable and may include respiratory, digestive, ocular, and neuromuscular symptoms (HOSSEININEJAD et al., 2011; LANGONI et al., 2013).

Toxoplasma gondii infection has acquired special importance as a waterborne disease (VITALIANO et al., 2015). The importance of the $\operatorname{dog}$ as a sentinel for infection and improper sanitation conditions in the riverside communities of the Cuiabá River, the wetland basin trainer of Mato Grosso, motivated this work for determining the occurrence of antibodies against $T$. gondii in dogs and to determine the variables associated with infection.

A sectional study was conducted in the coastal communities in Cuiabá River: Barranco Alto, Praia do Poço, Engenho Velho and Varginha, located in the municipality of Santo Antonio do Leverger (15 51'57"S and 56 04'37”O); Bom Sucesso and Passagem da Conceição, in the municipality of Várzea Grande (15'38'49"S and 56 $07^{\prime} 58^{\prime \prime} \mathrm{O}$ ) and the community of São Gonçalo Beira Rio, in the city of Cuiabá (153, $45^{\prime \prime} \mathrm{S}$ and $\left.56^{\circ} 05^{\prime} 49^{\prime \prime} \mathrm{O}\right)$. The main sources of financial income of these communities are fishing and tourism.

The dogs were sampled during home visits by census form. Each dog was represented by an epidemiological form containing information on breed, gender, age, diet, contact with cats, access to the street, presence of livestock and types of floor to detect possible factors associated with infection.

After consent of the owners, the dogs were contained, submitted to general clinical evaluation and approximately $5 \mathrm{~mL}$ of blood was collected by cephalic or jugular puncture after sterilization. The blood samples were transferred to a tube without anticoagulant, centrifuged at $5000 \mathrm{rpm}$ for 5 minutes and the serum obtained was stored at $-20{ }^{\circ} \mathrm{C}$ until serological analysis.

The presence of antibodies against $T$. gondii was assessed by immunofluorescence reaction (IFAT) using as antigen tachyzoites of $T$. gondii (RH strain) at a concentration of $1 \times 10^{7} \mathrm{Taq} / \mathrm{mL}$ and conjugated anti-dog IgG (Sigma Aldrich $\left.{ }^{\circledR}\right)\left(\right.$ CAMARGO, $^{\circ}$ 1964). Dog sera were tested in geometric progression, and were considered reagents for titration $\geq 1: 16$ (MOURA et al., 2009) compared with the positive and negative controls on each slide.

The prevalence values were calculated at the 95\% confidence intervals, and a chi-squared test $\left(\chi^{2}\right)$ with Yate's correction or Fischer's exact test was used to test for associations between the independent variable and the seroprevalence of anti- $T$. gondii antibodies in dogs using the EpiInfo 3.3.2 programme (CDC, Atlanta, USA). The variables with a $\mathrm{p} \leq 0.20$ in the univariate analysis were selected for the multiple analysis. The $\chi^{2}$ goodness-of-fit test was performed using the Hosmer and Lemeshow statistic, and $\mathrm{p} \leq 0.05$ was considered significant.

This work is in agreement with the Animal Experimentation Ethical Principles adopted by the Brazilian Society of Science in Laboratory Animals (SBCAL) and was approved by the Ethics
Committee on Animal Use (CEUA) -UFMT under the Protocol $\mathrm{N}^{\circ} 23108.014950 / 11-5$.

Of the 248 surveyed dogs, 107 (43.1\% [CI 37.1 to 48.8 ]) were seropositive for $T$. gondii. The seroprevalence found in the municipalities studied ranged from $25.6 \%$ to $64.3 \%$. The riverside community with the highest seroprevalence was Praia do Poço in Santo Antônio do Leverger with 64.3\% seropositive dogs. When analysing the prevalence by municipality, Várzea Grande had the highest prevalence with $47.1 \%$ (CI 36.8 to 57.5), followed by Santo Antônio do Leverger with 43.6\% (CI 35.3 to 51.9) and Cuiaba with 25\% (CI 14.3 to 48.8) (Figure 1). However, there was no statistically significant difference between them $(p>0.05)$.

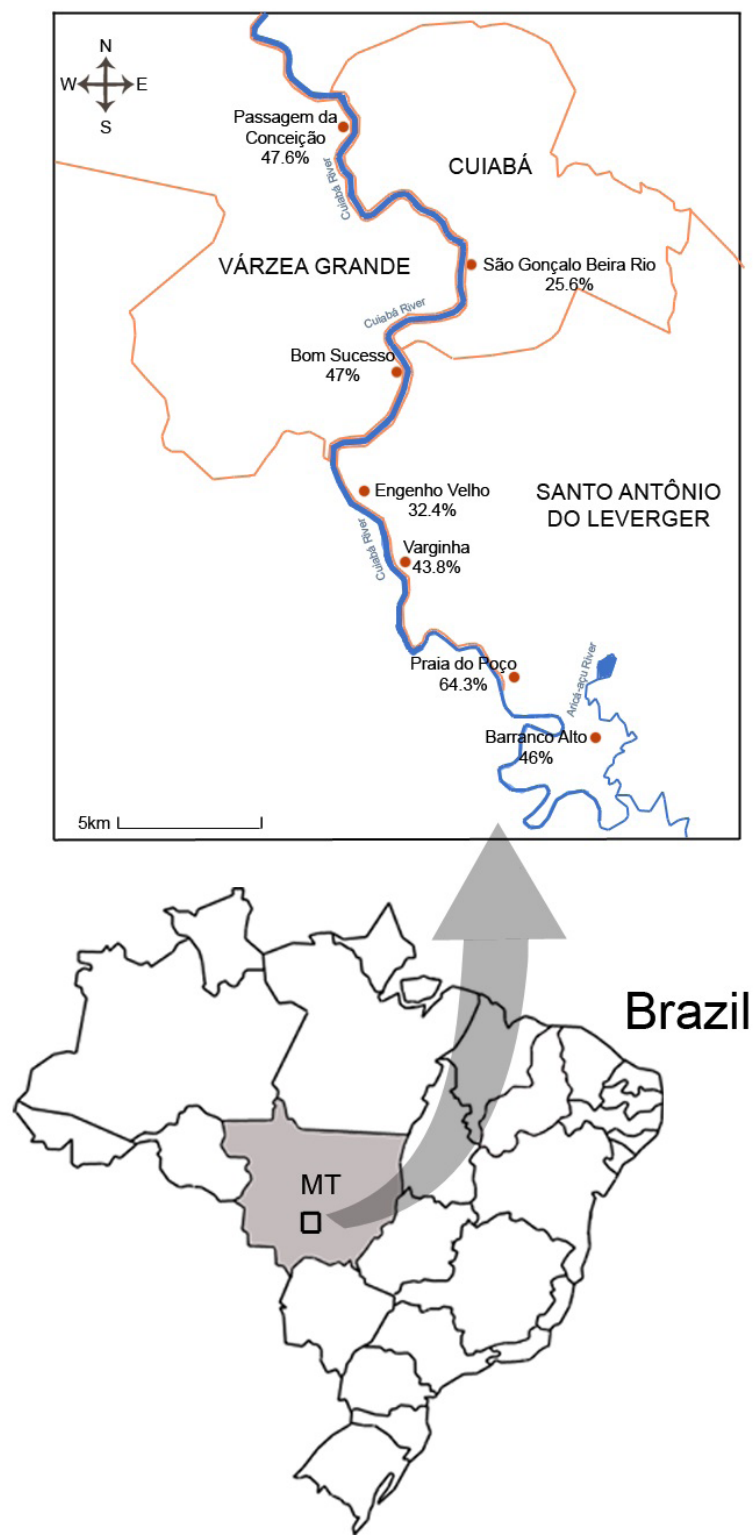

Figure 1. Location of riverside communities Pantanal surveyed. Seroprevalence for Toxoplasma gondii in dogs and location of Riverside Communities of São Gonçalo Beira Rio in the city of Cuiabá, Passagem da Conceição and Bom Sucesso in the municipality of Várzea Grande and Barranco Alto, Engenho Velho, Praia do Poço and Varginha in the municipality of Santo Antônio de Leverger, Mato Grosso. 
The antibody titres presented by seropositive dogs were 17 (1:16), 40 (1:64), 38 (1:256), 9 (1:1024) and 3 (1:4096). Of the 248 surveyed dogs, 101 (40.72\%) showed some clinical signs, of which 54 (53.46\%) had antibodies anti-T. gondii. The main clinical changes in the seropositive dogs consisted: lymphadenopathy, dermatopathy, ophthalmopathy, weight loss, anorexia and splenomegaly.

Among the surveyed dogs, the most common characteristics were undefined breed (88.7\%), males (64.1\%) and adults $(64.1 \%)$ (from one to six years), but there was no statistically significant difference in relating these variables and seroreactivity for T. gondii (Table 1). Concerning the possible environmental habits and aspects associated with infection in the univariate and multiple analysis, only the association with cats showed a statistically significant difference $(\mathrm{p}=0.02)$ (Table 1$)$.

The prevalence of infection by $T$. gondii in dogs is important because the dog is sentinel and determines the magnitude of environmental contamination by oocysts (MIRÓ et al., 2004). In this study, the prevalence of canine $T$. gondii infection was $43.1 \%$. However, prevalences greater than $60 \%$ have been detected in
Brazil and other countries (DREER et al., 2013; DAVOUST et al., 2015). In all surveyed communities, the prevalence was above $25 \%$, which was considered high. Although not statistically significant, the observation of different prevalence between communities can be explained by differences in the environmental characteristics (ALVARADO-ESQUIVEL et al., 2014). Furthermore, serological technique and used cut off explain different prevalences in Brazil and worldwide (BOA-SORTE et al., 2015).

The riverside communities of the Cuiabá River are characterized by subsistence farming, and some, like Bom Sucesso and Passagem da Conceição, in the municipality of Várzea Grande and São Gonçalo Beira Rio in Cuiabá, are considered tourist sites, presenting the best infrastructure conditions of the communities located in Santo Antônio de Leverger. However, this feature did not reduce the occurrence of infection of dogs by $T$. gondii. In a study conducted in the urban and rural areas of the city of Cuiabá, the prevalence (BOA SORTE et al., 2015) was similar to the average of the coastal communities; however, the prevalence was lower compared to the community of São Gonçalo Beira Rio in the same municipality.

Table 1. Analysis of the variables investigated in accordance with the seroprevalence of Toxoplasma gondii in the riverside communities of Mato Grosso, Central-Western Brazil.

\begin{tabular}{|c|c|c|c|c|c|c|}
\hline \multirow[b]{2}{*}{ Variables } & \multicolumn{2}{|c|}{ Dogs } & \multicolumn{2}{|c|}{ Univariate } & \multicolumn{2}{|c|}{ Multiple } \\
\hline & Total & Positive (\%) & P-value & $\begin{array}{c}\text { OR } \\
\text { (CI 95\%) }\end{array}$ & P-value & $\begin{array}{c}\text { OR } \\
\text { (CI 95\%) }\end{array}$ \\
\hline \multicolumn{7}{|l|}{ Breed } \\
\hline Mixed & 220 & $98(44.54)$ & 0.20 & 0.69 & --- & --- \\
\hline Pure & 28 & $09(32.14)$ & & $(0.21-1.36)$ & & \\
\hline \multicolumn{7}{|l|}{ Gender } \\
\hline Male & 159 & $69(43.39)$ & 0.91 & 0.97 & --- & --- \\
\hline Female & 89 & $38(42.69)$ & & $(0.56-1.64)$ & & \\
\hline \multicolumn{7}{|l|}{ Age groups } \\
\hline Indefinite age & 14 & $07(50.00)$ & 0.15 & --- & --- & --- \\
\hline$\leq 1$ year old & 46 & $15(32.60)$ & & & & \\
\hline$>1-3$ years old & 85 & $40(47.05)$ & & & & \\
\hline$>3-6$ years old & 74 & $28(37.83)$ & & & & \\
\hline$>6$ years old & 29 & $17(58.62)$ & & & & \\
\hline \multicolumn{7}{|l|}{ Diet } \\
\hline Commercial & 32 & $11(34.37)$ & 0.08 & --- & --- & --- \\
\hline Home-cooked & 64 & $35(54.68)$ & & & & \\
\hline Mixed & 152 & $61(40.13)$ & & & & \\
\hline \multicolumn{7}{|l|}{ Contact with cats } \\
\hline Yes & 61 & $34(55.73)$ & 0.02 & 1.96 & 0.02 & 1.96 \\
\hline No & 187 & $73(39.03)$ & & $(1.08-3.46)$ & & $(1.09-3.52)$ \\
\hline \multicolumn{7}{|c|}{ Access to the street } \\
\hline Yes & 189 & $87(46.03)$ & 0.09 & 1.63 & --- & --- \\
\hline No & 59 & $20(33.89)$ & & $(0.91-3.26)$ & & \\
\hline \multicolumn{7}{|l|}{ Livestock } \\
\hline Yes & 191 & $81(42.40)$ & 0.66 & 0.87 & --- & --- \\
\hline No & 57 & $26(45.61)$ & & $(0.48-1.65)$ & & \\
\hline \multicolumn{7}{|l|}{ Types of floor } \\
\hline Ground & 213 & $95(44.60)$ & 0.34 & --- & --- & --- \\
\hline Cemented & 09 & $02(22.22)$ & & & & \\
\hline Mixed & 26 & $10(38.46)$ & & & & \\
\hline
\end{tabular}


Similar to Dreer et al. (2013), 88.8\% of seropositive dogs had antibody titres between $1: 16$ to $1: 256$, which is considered low, diverging from the study in Cuiabá, Mato Grosso (BOA SORTE et al., 2015) where high titres of antibodies were prevalent. Differing rates of infection in clinical toxoplasmosis can be related to distribution and parasite efficiency. Low titres have been mentioned as resulting from a chronic stage or an early stage of infection (BARBOSA et al., 2003).

As in humans, T. gondii infection in dogs tends to be asymptomatic (HOSSEININEJAD et al., 2011). In this research, the frequency of healthy dogs and those presenting any clinical changes were similar; however, it is not possible to attribute such changes to infection by $T$. gondii, given the endemic nature of other diseases such as canine ehrlichiosis and canine visceral leishmaniasis (SILVA et al., 2010; ALMEIDA et al., 2012).

There was no age, gender, or racial predisposition, despite the prevalence being higher in adult dogs. This observation relates to the longer exposure time to the agent (AHMAD et al., 2014).

In relation to the environmental and management factors, such as the type of diet, free access to the street, a chicken coop and type of room floor, there was no significant association with infection by $T$. gondii. Although the diet was not associated with infection in this study, the supply of undercooked meat and fruits and vegetables unwashed increases the likelihood of infection by the possibility of ingestion of bradyzoites or oocysts (BRESCIANI et al., 2007; CARLOS et al., 2010). In addition, a study conducted in Brazil (BRESCIANI et al., 2007) found that dogs that living in an environment with a dirt yard were 11.5 times more likely to acquire the infection, reinforcing the possible soil contamination by staff members in areas surveyed. However, this aspect was not observed in this study, although $88.8 \%$ of positive dogs reside in an environment with a dirt yard.

Dogs that live with a domestic cat are approximately two times more likely to acquire infection. Living with cats has been associated with canine and human infection (FERREIRA et al., 2014), which is related to the ingestion of oocysts released in the cat faeces or environmental contamination by increasing exposure. However, a study of dogs in Mexico found no association between living with cats and T. gondii infection (ALVARADO-ESQUIVEL et al., 2014).

In conclusion, seroprevalence in the dogs of the riverside communities in the Baixada Cuiabana demonstrated high rates of infection, and contact with domestic cats was the main factor associated with infection.

\section{Acknowledgements}

This study was supported by the Fundação de Amparo à Pesquisa do Estado de Mato Grosso (FAPEMAT) - Grants: 285871/2010.

\section{References}

Ahmad N, Ahmed H, Irum S, Qayyum M. Seroprevalence of IgG and IgM antibodies and associated risk factors for toxoplasmosis in cats and dogs from sub-tropical arid parts of Pakistan. Trop Biomed 2014; 31(4): 777-784. PMid:25776604.
Almeida ABPF, Sousa VRF, Cruz FACS, Dahroug MAA, Figueiredo FB, Madeira MF. Canine visceral leishmaniasis: seroprevalence and risk factors in Cuiabá, Mato Grosso, Brazil. Rev Bras Parasitol Vet 2012; 21(4): 359-365. PMid:23184322. http://dx.doi.org/10.1590/S198429612012005000005 .

Alvarado-Esquivel C, Romero-Salas D, Cruz-Romero A, García-Vázquez Z, Peniche-Cardeña Á, Ibarra-Priego N, et al. High prevalence of Toxoplasma gondii antibodies in dogs in Veracruz, Mexico. BMC Vet Res 2014; 10(1): 191. PMid:25134696. http://dx.doi.org/10.1186/s12917-014-0191-x.

Barbosa MVF, Guimarães JE, Almeida MAO, Gondim LFP, Regis GB Freqüência de anticorpos IgG anti-Toxoplasma gondii em soros de cães errantes da cidade de Salvador-Bahia, Brasil. BrazJ Vet Res Anim Sci 2003; 40(6): 457-465. http://dx.doi.org/10.1590/S1413-95962003000600010.

Boa Sorte EC, Almeida ABPF, Cruz FACS, Gasparetto ND, Godoy I, Dutra V, et al. Serological and molecular detection of Toxoplasma gondii in dogs of urban and rural areas of Cuiaba, Mato Grosso. Semina: Ciênc Agrár 2015; 36(6): 3705-3712. http://dx.doi.org/10.5433/1679$0359.2015 \mathrm{v} 36 \mathrm{n} 6 \mathrm{p} 3705$.

Bresciani KDS, Costa AJ, Nunes CM, Serrano ACM, Moura AB, Stobbe NS, et al. Ocorrência de anticorpos contra Neospora caninum e Toxoplasma gondii e estudo de fatores de risco em cães de Araçatuba - SP. ARS Vet 2007; 23(1): 40-46. http://dx.doi.org/10.15361/2175-0106.2007v23n1p40-46.

Camargo ME. Improved technique of indirect immunofluorescence for serological diagnosis of toxoplasmosis. Rev Inst Med Trop Sao Paulo 1964; 6: 117-118. PMid:14177810.

Carlos RSA, Albuquerque GR, Bezerra RA, Sicupira PML, Munhoz AD, Lopes CWG. Ocorrência de anticorpos anti-Toxoplasma gondii e principais fatores de risco associados à infecção canina na região de Ilhéus-Itabuna, estado da Bahia. Rev Bras Med Vet 2010; 32(2): 115-121.

Davoust B, Mediannikov O, Roqueplo C, Perret C, Demoncheaux JP, Sambou M, et al. Serological survey of animal toxoplasmosis in Senegal. Bull Soc Pathol Exot 2015; 108(1): 73-77. PMid:25307881. http://dx.doi. org/10.1007/s13149-014-0403-4.

Dreer MKP, Gonçalves DD, Caetano ICS, Gerônimo E, Menegas PH, Bergo D, et al. Toxoplasmosis, leptospirosis and brucellosis in stray dogs housed at the shelter in Umuarama municipality, Paraná, Brazil. J Venom Anim Toxins Incl Trop Dis 2013; 19(1): 23. PMid:24066949. http:// dx.doi.org/10.1186/1678-9199-19-23.

Dubey JP, Lago EG, Gennari SM, Su C, Jones JL. Toxoplasmosis in humans and animals in Brazil: high prevalence, high burden of disease, and epidemiology. Parasitology 2012; 139(11): 1375-1424. PMid:22776427. http://dx.doi.org/10.1017/S0031182012000765.

Dubey JP. The history and life cycle of Toxoplasma gondii. In: Weiss LM, Kim K, editors. Toxoplasma gondii: the model apicomplexan: perspectives and methods. Hardbound: Elsevier; 2007. p. 1-17.

Ferreira AIC, Mattos CCB, Frederico FB, Meira CS, Almeida GC Jr, Nakashima F, et al. Risk factors for ocular toxoplasmosis in Brazil. Epidemiol Infect 2014; 142(1): 142-148. http://dx.doi.org/10.1017/ S0950268813000526. PMid:23507508.

Hosseininejad M, Malmasi A, Hosseini F, Selk-Ghaffari M, Khorrami N, Mohebali M, et al. Seroprevalence of Toxoplasma gondii infection in dogs in Tehran, Iran. Iran J Parasitol 2011; 6(1): 81-85. PMid:22347278.

Langoni H, Fornazari F, Silva RC, Monti ET, Villa FB. Prevalence of antibodies against Toxoplasma gondii and Neospora caninum in dogs. Braz J Microbiol 2013; 44(4): 1327-1330. PMid:24688530. http://dx.doi. org/10.1590/S1517-83822013000400043. 
Millán J, Chirife AD, Kalema-Zikusoka G, Cabezón O, Muro J, Marco I, et al. Serosurvey of dogs for human, livestock, and wildlife pathogens, Uganda. Emerg Infect Dis 2013; 19(4): 680-682. PMid:23750507. http:// dx.doi.org/10.3201/eid1904.121143.

Miró G, Montoya A, Jiménez S, Frisuelos C, Mateo M, Fuentes I. Prevalence of antibodies to Toxoplasma gondii and intestinal parasites in stray, farm and household cats in Spain. Vet Parasitol 2004; 126(3): 249255. PMid:15567588. http://dx.doi.org/10.1016/j.vetpar.2004.08.015.

Moura AB, Souza AP, Sartor AA, Bellato V, Teixeira EB, Pisetta GM, et al. Ocorrência de anticorpos e fatores de risco para infecção por Toxoplasma gondii em cães, nas cidades de Lages e Balneário Camboriú, Santa Catarina, Brasil. Rev Bras Parasitol Vet 2009; 18(3): 52-56. PMid:19772776. http:// dx.doi.org/10.4322/rbpv.01803009.

Silva JN, Almeida ABPF, Boa Sorte EC, Freitas AG, Santos LGF, Aguiar $\mathrm{DM}$, et al. Soroprevalência de anticorpos anti-Ehrlichia canis em cães de Cuiabá, Mato Grosso. Rev Bras Parasitol Vet 2010; 19(2): 108-111. PMid:20624348. http://dx.doi.org/10.4322/rbpv.01902008.

Souza SLP, Gennari SM, Yai LEO, D’Áuria SNR, Cardoso SMS, Guimarães JS Jr, et al. Occurrence of Toxoplasma gondii antibodies in sera from dogs of the urban and rural areas from Brazil. Rev Bras Parasitol Vet 2003; 12(1): 1-3.

Vitaliano SN, Mendonça GM, Sandres FAM, Camargo JSAA, Tarso P, Basano SA, et al. Epidemiological aspects of Toxoplasma gondii infection in riverside communities in the Southern Brazilian Amazon. Rev Soc Bras Med Trop 2015; 48(3): 301-306. PMid:26108008. http://dx.doi. org/10.1590/0037-8682-0040-2015.

Zhang XX, Cai YN, Wang CF, Jiang J, Xu YT, Yang GL, et al. Seroprevalence and risk factors of Toxoplasma gondii infection in stray dogs in northern China. Parasitol Res 2015; 114(12): 4725-4729. PMid:26403980. http:// dx.doi.org/10.1007/s00436-015-4746-y. 